\title{
Managing Value Co-Creation through Interfaces with Suppliers
}

\author{
Catarina Roseira ${ }^{1} \&$ Carlos Brito ${ }^{1}$ \\ ${ }^{1}$ Faculty of Economics, University of Porto, Porto, Portugal \\ Correspondence: Carlos Brito, Faculty of Economics, University of Porto, Rua Roberto Frias, 4200-464 Porto, \\ Portugal. Tel: 351-22-557-1100. E-mail: cbrito@fep.up.pt
}

Received: January 20, 2014

Accepted: February 20, 2014

Online Published: March 26, 2014

doi: 10.5539/ibr.v7n4p11

URL: http://dx.doi.org/10.5539/ibr.v7n4p11

\begin{abstract}
The growing specialization of firms and the reinforcement of vertical disintegration have led to an increasing reliance on purchasing and supply management. This means that an increasing proportion of value is created outside the boundaries of the firm, namely by suppliers. In this context, the paper aims to relate the configuration of the bonds companies establish with their suppliers to the process of value creation. On the basis of a case study approach, the paper furthers our understanding of buyer-supplier relationships as mechanisms for the coordination and development of capabilities on both sides of the dyad. Evidence was found that relationships affect not only the access and exploration of suppliers' resources, but also the perception the buying firm has about their capabilities which is likely to condition the potential for joint value creation. The main contribution of the paper is that co-creating value with suppliers is not a recipe. It is not the 'right' solution in all instances. Rather, value co-creation involving suppliers must be regarded as a strategic option which depends on several conditions. This research puts in evidence two of these conditions: suppliers' capabilities and the way the buyer-seller relationships are configured.
\end{abstract}

Keywords: buyer-supplier relationships, capabilities, relationship configuration, value creation

\section{Introduction}

Firms have been reformulating their business models and competitive bases leading to a growing specialization and interdependency with suppliers (Florén \& Lee, 2013; La Rocca \& Snehota, 2014). Firms are increasingly involving suppliers in the development of new products and facing new management problems as reported in several studies (Croom \& Batchelor, 1997; Handfield, Ragatz, Petersen, \& Moncza, 1999; Ragatz, Handfield, \& Petersen, 2002; Petersen, Handfield, \& Ragatz, 2005; McIvor, Humphreys, \& Cadden, 2006; Wagner \& Hoegl, 2006, Valjakka, Kansola, Hakanen, \& Valkikari, 2013; Rosell, Lakemond, \& Wasti, 2014). Innovation, in particular, has received a special attention of researchers (Oinonen \& Jalkala, 2012; Martinez, 2013). In this context, supplier management deals with issues of substantial diversity. Firms buy very different things from their suppliers (e.g., standardized products, development activities, information, brands and even reputation) and this requires different capabilities both from the customers and the suppliers' side.

From the supplier side, the creation of value for customers has been considered a key issue in buyer-seller relationships (Wilson \& Jantrania, 1995; Hogan, 2001; Eggert \& Ulaga, 2002; Möller \& Törrönen, 2003; Ulaga, 2003; Ulaga \& Eggert, 2005, 2006; Moeller, Fassnacht, \& Klose, 2006). Researchers in business-to-business marketing have focused their efforts in understanding such value both at the relationship level (Boyd \& Spekman, 2004; Hammervoll, 2005; Möller, 2006; Aarikka-Stenroos \& Jaakkola, 2012) and at the network level (Baxter \& Matear, 2004; Ehret, 2004; Eng, 2005; Holmen, Aune, \& Pedersen, 2013; Mena, Humphries, \& Choi, 2013). However, value is not only created by the seller who delivers it to the buyer. Rather, in most cases it is co-created by both parties through collaborative processes that involve the access to mutual resources and capabilities as well the coordination of activities (Mele, 2008; Grönroos, 2011; Day, Fawcett, Fawcett, \& Magnan, 2013).

Over the past few years, significant research has been conducted on value co-creation. Möller (2006), adopting a value-creation logic approach, introduces the role of competences in creating customer value. Matthyssens, Vandenbempt, and Berghman (2006) relate value creation to the innovation process. And more recently, a number of authors address value co-creation (e.g., Cova \& Salle, 2008; Lindberg \& Nordin, 2008; Matthyssens \& Vandenbempt, 2008; Vargo \& Lusch, 2008; Leroy, Cova, \& Salle, 2012; Engelseth \& Törnroos, 2013; Roser, DeFillippi, \& Samson, 2013; Randall, Wittmann, Nowicki, \& Pohlen, 2014). Nonetheless, most of the research 
focuses on the customer side. For instance, Grönroos (2006, p. 234) says that "suppliers only create the resources or means to make it possible for customers to create value for themselves. (...) When suppliers and customers interact, they are engaged in co-creation of value". And Vargo and Lusch, in a set of papers that are considered landmarks in this field (Lusch \& Vargo, 2006a, 2006b; Vargo \& Lusch, 2004a, 2004b), explore the way value is constructed: "the customer is always a co-creator of value" (Lusch \& Vargo, 2006b, p. 284). More recently, O'Cass and Ngo (2012) show how product innovation and marketing influence the ability to co-create value for B2B firms on the basis of suppliers' capabilities. By co-creating both the meaning and function of their experiences, customers co-generate value for themselves (Chakkol, Johnson, Raja, \& Raffoni, 2014).

This puts in evidence the strategic importance of supply management for value creation and the growing interest for buyer-supplier relationships (Gadde \& Persson, 2004; Menon, Homburg, \& Beutin, 2005; Ivens, Vijver, \& Vos, 2013). However, there seems to be substantial gaps in how firms actually manage their supplier relationships and its impact on value creation. Möller (2006, p. 914), in an article on value creation, states that "there is a clear need for research that explores inter-organizational collaboration in value-production where the traditional roles of suppliers and customers are becoming more complex and intertwined, and where the players have to be able to develop new collaborative competences". Later, Wagner, Eggert and Linmann $(2008$, p. 1) declare that "researchers have almost exclusively focused on value once it has been created and shared among the respective relationship partners. (...) It comes as a surprise that conceptual as well empirical research on value creation and value sharing in collaborative relationships remains so limited". More recently, Kim, Cavusgil, and Cavusgil (2013, p. 880) state that "despite the potent of value creation, most studies focus on the importance of creating customer value through individual firm's efforts (...) ignoring the potential from the collaborative efforts among supply chain partners". Indeed, little is known about the type of goals or benefits industrial firms look for in their suppliers and how these goals condition the way they relate to each other. Since what suppliers do for their customers strongly depends on the actions of customers themselves (Gadde \& Persson, 2004), it seems useful to have a better understanding of how suppliers' resources and capabilities are perceived and managed. In this context, the paper aims to relate the configuration of the relationships companies establish with their suppliers to the process of value creation.

The article is organized as follows. In the second section, we review some central concepts of both the Industrial Marketing and Purchasing (IMP) group and the Capabilities Approach that are combined in the third section to produce the conceptual model that has guided the interpretation of our empirical data. The section which follows addresses the methodology used in the research process. The fifth section describes the cases studied, and is followed by a section where the research findings are presented and discussed. Finally, the paper concludes with a discussion of the main theoretical and managerial contributions.

\section{Theoretical Background}

This section focuses on some of the IMP and Capabilities Approach's basic concepts that seem especially relevant in the context of value creation in supply management. The discussion of the complementarities between these approaches will lead to the identification of some issues that, despite their relevance, are still not fully explored and constitute the focus of this paper.

\subsection{The IMP Perspective on Supply Management}

IMP researchers have been extensively studying industrial relationships concluding that they may assume a wide range of configurations according to their characterization in several dimensions, such as their atmosphere, continuity, complexity, intensity, symmetry (Håkansson \& Snehota, 1995; Ford et al., 1998) or interfaces (Araújo, Dubois, \& Gadde, 1999). Several authors (cf. Blois, 1998; Gadde \& Snehota, 2000) contend that relationships must be managed according to the costs and benefits accruing to firms from those relationships. A possible way to analyze this issue is to consider the effects that firms are trying to achieve in their supplier connections.

IMP authors (cf. Håkansson \& Johanson, 1993; Anderson, Håkansson, \& Johanson, 1994; Ford \& McDowell, 1999) have emphasized that relationships in industrial settings have both direct and indirect functions. Direct functions produce effects such as cost reduction, product quality, volume and sourcing safeguard. Indirect functions can result in network developing (suppliers work as bridges between the customer and other actors), information scouting (customers obtain market or technical information through suppliers) and innovation development. In short, while direct functions are related to efficiency goals, indirect functions are associated with innovation (products, processes, markets) goals (Walter, Müller, Helfert, \& Ritter, 2003). The importance of indirect functions is that they are a sine qua non condition for value co-creation between buyers and sellers (Möller, 2006).

Direct and indirect functions produce direct and indirect effects. Direct effects emerge from, or are reflected 
upon, the relationship of dyadic counterparts. Indirect effects emerge from, or are reflected upon, relationships between dyadic counterparts and other actors. As Ford and McDowell (1999) explain, while some of these effects may be managed and controlled, others are unintended or even unforeseen by one or both relationship participants.

Goal setting and relationship configuration are considered to be essential elements for value creation in supply management. The value of a supplier relationship depends on the customer's goals, operations, strategy and other relationships and, consequently, cannot be deducted directly from the products and services being exchanged (Ford et al., 2003; Gadde \& Snehota, 2000). Rather, the value of a supplier depends on its ability to perform the functions sought by the customer, and this ability depends on his endowment of capabilities (Möller \& Törrönen, 2003). The analysis of suppliers' capabilities may help to evaluate their potential to produce the desired effects. As argued by several authors (Araújo et al., 1999; Ford et al., 2003; Gadde \& Persson, 2004), increasing efficiency or achieving innovation goals requires different combinations of distinct capabilities on both sides of the dyad.

However, the existence of adequate supportive capabilities does not assure their full exploration. The type of relationship connecting customers and suppliers, e.g., the roles played by the actors, their posture within the relationship and the structure of interfaces condition how capabilities and resources will be explored in order to create value (Gadde \& Persson, 2004), e.g., the degree of supplier integration in the developing new products (Petersen, Handfield, \& Ragatz, 2005). Interfaces translate the technical interdependencies between customers and suppliers and constitute an important dimension of industrial relationships. Araújo et al. (1999) identify four types of interfaces - standardized, specified, translated and interactive. In standardized interfaces, the customer buys a standard product benefiting from the supplier's economies of scale and scope. In specified interfaces, products are manufactured according to the customer's specifications and suppliers are mainly used as production capacity buffers. In translated interfaces, the supplier embodies into a specific product the functionalities required by the customer. Finally, in interactive interfaces products are co-produced by both parties fostering the combination of their knowledge. Different interfaces have a different impact on the utilization of both customers and suppliers resources, capabilities, costs, productivity, learning and innovation potential.

In addition, supplier management reflects firms' subjective perceptions of their counterparts' ability to create value (Makkonen \& Olkkonen, 2013; Roseira, Brito, \& Ford, 2013). To be considered valuable, suppliers' resources and capabilities must be seen as important contributions to the relationships (Johnsen \& Ford, 2006, 2008). On the one hand, the perception and evaluation of resources and capabilities influence the expectations about the benefits that can be extracted from relationships and, consequently, the interest in investing in those relationships. On the other hand, this subjective evaluation also includes the adequacy of relationship types to the goals defined for each supplier. For instance, cost reduction can be achieved by establishing distant relationships with several suppliers and by fostering competition among them. Conversely, lower prices and other cost reductions often reward customer loyalty (Cannon \& Homburg, 2001) or result from the concentration of purchases in a small number of suppliers (Avery, 1999; Birch, 2001). Thus, similar supply goals can be achieved through different relationship types according to the subjective perception of the association between goals and relational configurations.

In sum, buyer-supplier relationships have been an important focus of interest in the IMP approach. The notion of direct and indirect functions and the suggestion that suppliers' capabilities can be seen as a precondition to suppliers' ability to perform specific functions constitute important elements for a better understanding of how value is co-created in industrial networks. However, the issue of capabilities that has been gaining a higher prominence in the IMP approach is still insufficiently explored. In this context, the Capabilities Approach can be a valuable contribution to a better understanding of relationships as a form to organize the access to suppliers' capabilities.

\subsection{The Capabilities Approach}

In order to produce and sell a good or a service, firms plan and execute processes requiring the coordination of several internal and external activities (Richardson, 1972, 1998). To coordinate complementary and dissimilar external activities, firms must create relations with each other, i.e., build an external organization, and this requires the development of specific capabilities. In the same vein, Loasby $(1996,1998 \mathrm{a})$ argues that firms must access the knowledge they do not own but still need to be successful. In order to do so, firms need to build a set of relationships with specific counterparts (an external organization) and to develop an adequate bundle of direct and indirect capabilities. Direct capabilities consist of knowing how to "make things" and indirect capabilities of 
knowing how to "get things done by others" (Loasby, 1998a). Indirect capabilities allow firms to specialize while accessing the complementary capabilities detained by their suppliers (Araújo et al., 1999). Furthermore, Araújo et al. (2003) state that suppliers' capabilities can be 'merely' accessed, explored or even developed in combination with the customers' capabilities. As such, inter-firm relations may be used not only to access capabilities that firms do not control but also to influence them (Handfield et al., 1999; Mota \& Castro, 2005). Accessing or influencing external capabilities is likely to require different relational capabilities and relational formats.

In addition, it is also suggested that a distinction must be made between activity division-i.e., who designs and manufactures (producing) - and knowledge division - i.e., who holds the knowledge to do it. Firms may outsource activities or knowledge (Fine \& Whitney, 1996). In the former case, suppliers work as a mere extension of the customer's production capacity, as the customer is able to develop and produce the input and retains the knowledge required to do so. In the latter case, since the customer is not able to produce the input, it buys the input as well as the knowledge embedded in it. Thus, as suggested by Brusoni and Prencipe (2001), firms may know more than they make. As inter-firm coordination of activities normally requires some degree of overlapping knowledge, activity boundaries tend to be narrower than knowledge boundaries (Richardson, 1972; Dubois, 1998).

The choices about activities and knowledge sharing, i.e., their boundaries, are more decisive than the apparently simple decision about make-or-buy. This decision deals with the option between direct or indirect control of capabilities (Loasby, 1996, 1998b). Direct (or proprietary) control of capabilities is unnecessary if a firm is able to access them effectively through its counterparts (Araújo et al., 2003). Furthermore, the preference for control reduces the firm's dependency on knowledge and capacity, but also reduces the possibility of creating new knowledge, as this arises from the diversity of conjectures held by different firms (Foss \& Loasby, 1998). Thus, if a firm is looking for innovation effects, inter-firm relationships are, from this point of view, more effective than the development of internal activities and capabilities, performed within a firm's idiosyncratic framing.

While firms try to access simultaneously different types of suppliers' capabilities according to their needs and goals (Gelderman \& van Weele, 2005; Wagner \& Johnson, 2004), they must also decide if they want to do it in a more static or dynamic way. Loasby (1998b), Araújo et al. (1999) and Foss (1999) state that firms use static capabilities to optimize existent resources (e.g., in terms of economies of scale and scope), and dynamic capabilities to integrate, develop and re-configurate internal and external capabilities and resources. Loasby (1998b) also stresses the need to focus on the range of future activities that capabilities make possible and on the possibility of shaping the capabilities themselves. In a similar view, Araújo et al. (1999) argue that rather than evaluating suppliers' current offers that express their static efficiency, customers should evaluate supplier's capabilities that shape their dynamic efficiency and condition their potential to add value to the customer's business.

In short, the Capabilities Approach offers a rich view on the type of capabilities that firms can develop internally or access through their suppliers in order to create value. In this perspective, the access of suppliers' capabilities cannot be separated from the organization of this access, namely through an adequate investment in inter-firm relationships and capabilities' structures and the definition of adequate counterpart boundaries. However, it still seems insufficient for understanding buyer-supplier value creation, the type of goals or effects that industrial customers try to obtain through the relationships and how these goals are related to the relationships' organization, namely how activities and capabilities are shared, and boundaries contracted or expanded in interaction processes. The next section combines the IMP and Capabilities Approach into a framework to analyze the links between the type of goals (translated in value-creating functions and supporting capabilities) to be explored in suppliers and the configuration of relationships designed for that purpose.

\section{Research Questions and Framework for Analysis}

The notion of interaction, central to the IMP conceptual framework, complements and furthers Richardson's (1972) views on the external organization and inter-firm relations as coordination mechanisms. The Capabilities Approach seems to regard the access of external resources, activities and capabilities as the result of firms' ability to make the adequate investments, namely in their structure of direct and indirect capabilities (cf. Foss \& Loasby, 1998). The IMP perspective has a more complex view on this issue, by contending that customer and supplier interact according to their interests, visions and strategies (cf. Ford et al., 2003; Gadde \& Snehota, 2000). As such, the role of suppliers, insufficiently addressed by the Capabilities Approach, is more central in the IMP literature. Authors of this stream of research suggest that suppliers' capabilities are a pre-condition to perform the direct and indirect functions - including value co-creation - that express supplier management goals (Möller \& 
Törrönen, 2003). Inasmuch as the IMP literature does not specify the nature of those capabilities, the multiple definitions offered by the Capabilities Approach are an important element to explore that gap.

It is expected that direct or efficiency functions are supported by static capabilities while indirect or co-creative functions are supported by dynamic capabilities (Figure 1). Furthermore, as firms move from the exploration of efficiency functions to innovation functions their mix of capabilities may need to exhibit a growing proportion of indirect and knowledge oriented capabilities as compared to direct and product oriented capabilities. In this case, the ability to co-create value is necessarily higher given the interdependence and goals of both parties (Araújo et al., 2003; Foss, 1999; Loasby, 1998a, 1998b).

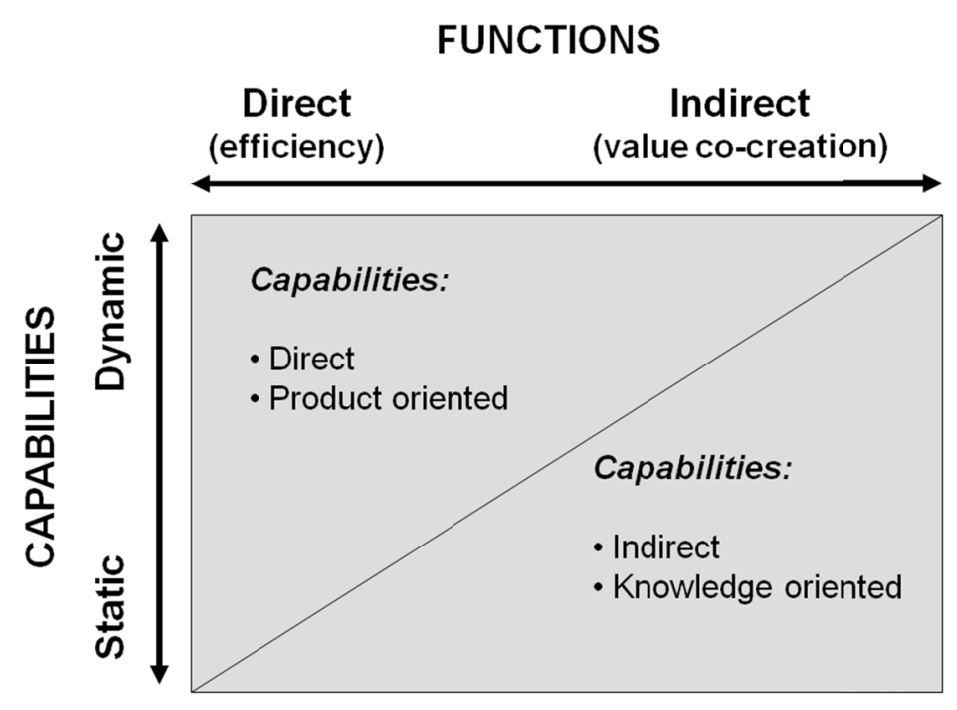

Figure 1. Capabilities and value co-creation

The existing literature stresses the omnipresent effect of capabilities on firms' abilities to perform specific relationship functions (Möller \& Törrönen, 2003). But this connection can assume the opposite direction as different types of relationship functions may impact suppliers' capabilities, namely through the optimization, reconfiguration and development of those capabilities (Araújo et al., 2003, Loasby, 1998a, 1998b; Mota \& Castro, 2005). For example, while exploiting the same type of functions with suppliers may lead to the optimization of supporting capabilities, exploring new functions (e.g., moving from direct to indirect functions) probably requires some type of reconfiguration or even the development of new capabilities. In short, this bi-directional nature of indirect functions is one the basis of value co-creation. In other words, while direct functions are related to more one-side creation of value and its delivering to the customer, indirect functions are preconditions for the creation of value by both buyer and seller.

Both the IMP and the Capabilities Approach perspectives seem to share the idea that the exploration of supplier functions or capabilities is conditioned by the firm's ability to make adequate investments in its own technical and relational capabilities. These issues, which are well developed at a theoretical level, seem to leave room for further research on value co-creation.

The objective of this paper is to relate the configuration of the relationships companies establish with their suppliers to the process of value creation. This process depends on two factors: (i) the capabilities of the suppliers and the functions sought by the buying company; (ii) the way suppliers are managed. In this regard, the main goal of the paper gives rise to the following research questions:

-How do supplier's functions and capabilities condition the configuration of buyer-supplier relationship?

-How does the supply management process affect the configuration of buyer-supplier relationship?

Figure 2 presents an integrated framework that will guide our analysis. It shows the link between value creation and relationships configuration. Firstly, it addresses the role of supplier's functions and capabilities which has to do with the first research questions (Q1). Secondly, it also takes into account the process of supply management which is related to the second research question $(\mathrm{Q} 2)$. 


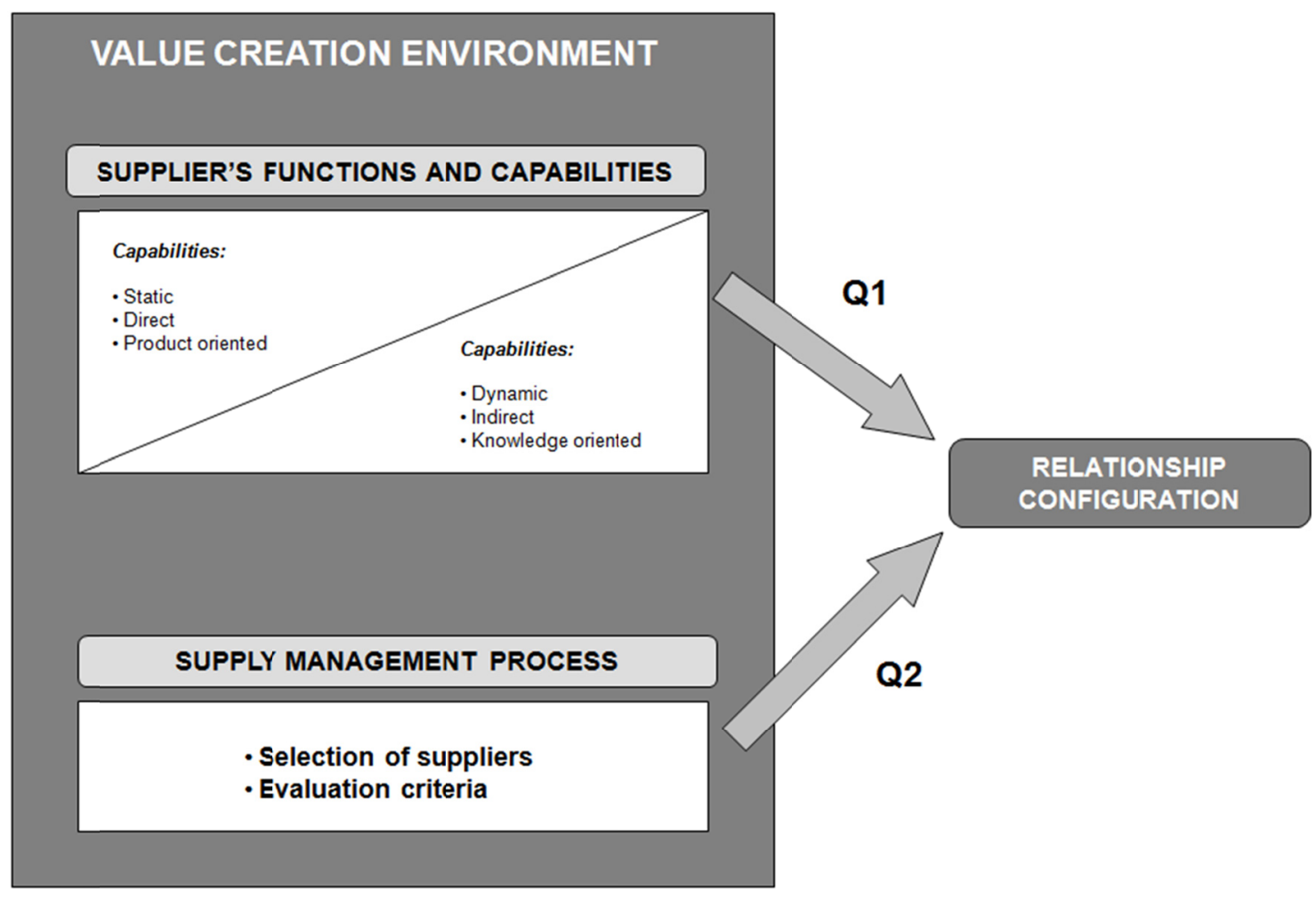

Figure 2. A framework for the analysis of buyer-supplier relationship management

The access of functions and their supporting capabilities is also framed by the supply management process and the type of relationships they are able and willing to mutually develop (Johnsen \& Ford, 2006, 2008). Value co-creation requires that supplier capabilities are used to full advantage, and so they must be recognized by the customers and considered a valuable contribution. This framework suggests that selection and evaluation criteria are important factors in the way capabilities are perceived. In a simplified way, selection criteria may be considered a proxy to the type of functions that customers are looking for in their suppliers; and the actual selection may be seen as the recognition that suppliers have the adequate capabilities to perform those functions. The evaluation criteria and the selection process may also be indicators of which suppliers' dimensions are considered vital and of how effectively their capabilities are actually being used to perform the required functions.

The perception of suppliers' capabilities is also an important issue in relationship configuration. The configuration of relationships, e.g., in terms of continuity, complexity, intensity, symmetry (Håkansson \& Snehota, 1995; Ford et al., 1998), actor's posture (Gadde \& Persson, 2004) and interfaces (Araújo et al., 1999), to be established with suppliers is driven by, among other factors, customers' goals for each of them and by the evaluation of suppliers' capabilities (Möller \& Törrönen, 2003). If these are considered valuable, the customer has to develop an interactive process that enhances their effective utilization. Furthermore, relationship configuration is likely to affect the perception of capabilities (Barnes et al., 2007). This may lead to an eventual revision of the selection and evaluation criteria which means an additional effect on how and what type of supplier capabilities will be explored by the customers.

\section{Research Methodology}

To investigate the issues systematized in the framework, the research adopted an abductive case study approach. Literature suggests that the cases' relevance to the investigation goals (George \& Benett, 2005) and their learning potential (Dubois \& Gadde, 2002) are essential factors in case selection. The selection's main goal was to clarify if and how the configuration of supplier relationships is associated with the different functions suppliers are sought to perform and with the access of suppliers' capabilities. As such, the basic guideline in selecting the cases was to have a situation where the customer would be seeking mainly to explore direct functions in their supplier relationships, and another case where the supplier functions would be mainly of an indirect nature. This differentiation would allow investigating the links between functions and capabilities and also of how these links 
are reflected upon and framed by the process of developing and managing supplier relationships.

With this in mind, two industrial firms were selected: Adira, a manufacturer of machinery to cut steel, and Bosch Termotec, a manufacturer of gas-fired hot water systems. The selection was based on exploratory interviews conducted in both firms to verify their adequacy to the research problem. These interviews involved the managers holding the higher authority over supplier management and confirmed their differentiation in terms of supplier functions: Adira mainly looks for direct functions while Bosch Termotec is mainly focused on indirect functions. The selection of the cases and the analysis of the data followed a process close to the configuration analysis proposed by Ragin (2000). Each case was analyzed individually in order to understand how the several dimensions combine to form different configurations of the same phenomenon, followed by a comparative analysis between the two cases in order to identify and explain their (dis)similarities.

The use of two cases is a limitation but offers a great potential for research (Dubois \& Araújo, 2004). On the one hand, it is obvious that the findings of this research cannot be straightly generalized, requiring additional research on the basis of other cases or a quantitative approach. However, we have positioned our investigation mainly as exploratory. In this regard, the use of two cases offers the potential to develop a deeper analysis raising issues that otherwise would be difficult to find out. And, following many IMP researchers (cf. Easton, 1995, 1998; Halinen \& Törnroos, 1995; Dubois \& Gadde, 2002; Hedaa \& Törnroos, 2008) this is likely to be potentially fruitful in network studies.

Data was collected through semi-structured interviews conducted in the two focal firms and 31 suppliers. In order to capture the multidimensional nature of supply management, the research included managers of several functional areas (purchasing, quality, R\&D, logistics, production). One member of each firm's board was also interviewed to reveal how supplier strategies fit in their corporate strategies. A total of 14 managers from the two focal firms were interviewed. The suppliers' interviewees embodied the relationship with the focal firms for several years, constituting excellent informants about the issues under study. In all cases but one, the interviews were conducted in the supplier firms and were followed by a visit to the premises. The interviewing was a cumulative process that included as many informants as necessary to saturate the categories under study (Eisenhardt, 1989; Strauss \& Corbin, 1998). All interviews were taped, transcribed and their analysis was supported by Nud*ist 6 software. Internal documents, Internet sites and press articles were also used as sources of information about the focal companies and their suppliers.

\section{Case Studies}

\subsection{Case 1-Adira}

Adira is one of the largest Iberian machinery manufacturers. Purchase goods account for $45 \%$ of production costs. A manager defined Adira as a "highly vertically integrated company". The company has two main types of suppliers: catalog suppliers and subcontracted suppliers. Catalog suppliers range from multi-brand representatives to national agents or international firms such as Bosch or Siemens, selling standardized materials and components. Product standardization enables the focal company to buy the same component from different suppliers "keeping its independence". Relationships with catalog suppliers are normally long with low intensity (less than one contact per month) and complexity (one, or at most a few people from Adira are involved). Subcontracted suppliers range from micro to medium-size firms that manufacture parts according to Adira's specifications. Adira performs the activities of all but one of his subcontracted suppliers, ensuring a strong control over their processes, costs and prices. Subcontracted suppliers are highly (sometimes totally) dependent on the purchases of Adira and, in several cases, they also buy raw-materials and production tools from the focal company. Relationships with subcontracted suppliers are long, intense (sometimes several contacts per day) and complex (involving several people from Adira).

The division of activities and interfaces between Adira and its suppliers has remained the same throughout the years, as machines have always been developed internally with little contribution from the suppliers. Subcontracted suppliers have always been managed through specified interfaces: Adira sets materials/parts and, sometimes, production processes' specifications and suppliers execute the production activities. Subcontracted suppliers are considered as "external workstations" used to pursue direct/efficiency functions: lower costs, higher flexibility and sourcing safeguarding. Catalog suppliers are managed through standardized interfaces - standardized products are developed internally and without interference from the customer and sold to a variety of other users from different industries. Adira may ask them for some advice for the best options available in their catalogs but the integration of components in Adira's machines is carried out by the customer, exclusively.

This view of Adira's managers is that apart from the international manufacturers, suppliers have very limited 
capabilities, restraining the possibility of involving them in more complex tasks. The smallest suppliers acknowledge their limited capabilities and lack of interest in moving from manufacturing tasks to more complex ones. The case is quite different with the larger suppliers (subcontracted or catalog) that hardly recognize themselves in the picture drawn by the focal company. Some of them say that they would be able and willing to be more active in areas such as product development, as they do with other customers, but they do not foresee this evolution, which would collide with Adira's strong internal orientation anchored in a highly competent team. Similarly, Adira recognizes that involving a few specific suppliers in the development phase could be potentially positive, but this is not done because it is not in the company tradition.

The major benefits the focal company looks for when selecting suppliers are low prices, product quality/reliability, flexibility and availability. Evaluation process is centered on three main aspects - quality/reliability, prices and speed of delivery. Quality is the clearly dominant factor-from the 84 maximum points that suppliers can achieve, 64 focus on organizational or product aspects related to quality, 10 focus on prices and financial terms, 7 on logistic issues and 3 on relational dimensions. Selection and evaluation processes are consistent with each other and also with the goals of efficiency/rationalization that Adira seeks to achieve through its suppliers.

\subsection{Case 2-Bosch Termotec}

Bosch Termotec (formerly named Vulcano) was founded in 1977 to produce gas-fired hot water systems under a Bosch technological license. The company was designated as competence center of Robert Bosch for gas-fired hot water systems in 1993, and is presently fully owned by this international group. Although the company has outsourced some production activities in the last years, its managers think that it is still too vertically integrated and needs to continue the outsourcing process and concentrate further on its core competences-instant production of hot water. Bosch Termotec's supplier base comprises medium to large-size, local or foreign companies that have or must develop "a minimal structure of resources in quality, logistics, manufacturing, development and management".

Bosch Termotec's relationships with its suppliers are generally long lasting and perceived as positive by both sides inasmuch as they are likely to create value by both customer and seller. Throughout the years, activities, resources and interfaces have been changing due to the evolution of Bosch Termotec and its supplier strategy and the evolution of suppliers' resources and capabilities. Almost all purchased parts are customized to the focal company's needs. Traditionally, Bosch Termotec specified all parts' details (functions, materials, dimensions), and suppliers manufactured them. In the last 5-6 years, Bosch Termotec's development team has been actively seeking suppliers' assistance to develop the parts. Interfaces are specified or interactive. Interactive interfaces are especially common in areas where Bosch Termotec has insufficient production or knowledge capabilities and does not wish to develop them (like electronics). However, even when specified interfaces are used (e.g., suppliers of outsourced activities), they normally assume an interactive nature, as the focal company expects all suppliers to "proactively produce and suggest new solutions in terms of product specifications, materials or processes". Relationships' complexity and intensity vary according to the buying process phase- they are high during the parts' development or modification phases and lower after the parts enter the regular production phase, when contacts become less frequent and concentrated in the logistic area.

The processes of selecting and evaluating suppliers are based on several criteria. Aspects like quality, price, flexibility and continuous sourcing are relevant, but considered as mere qualifying factors. Dynamic and indirect capabilities are what really differentiate suppliers, e.g., their ability to assist in parts development or to be able to "develop a vision of the business, of the complementarities rather than just of the product or the manufacturing". In this context, suppliers' networks of customers are an important selection criterion, as they help to evaluate whether or not suppliers have enough critical mass to undertake the investments needed to support the focal firm's goals. Additionally, suppliers' relationships with other customers are seen as a source of diversity and as learning opportunities that may reflect positively on Bosch Termotec.

The evaluation process calls for the equal participation of three areas - purchasing, quality and logistics. It is a mix of quantitative and qualitative components that constitute an important basis to decide upon how to manage each relationship (maintain, develop, invest, withdraw, etc.). As suppliers' current offers are less prized than their potential to add value to Bosch Termotec's own business, and this is hardly evaluated through "formal metrics", subjective evaluation is of outmost importance. As the Quality Manager explains, "the question "what is your opinion about this supplier?', even if we have a formal evaluation of that supplier, is information, which is as important, or even more so, than all the accounting of deliveries". In fact, technical excellence is only valued if, at the same time, suppliers understand the focal firm's business and how their activities and capabilities can be 
proactively used to enhance the customer's products or to reduce its costs.

\section{Research Findings}

Having described each case, we now turn to their comparative analysis. The links between relationship configurations, suppliers' functions and capabilities, and the supply management process will be the main focus of our analysis to understand value creation. The sections which follow address each of the research questions explained in Section 4.

\subsection{Suppliers' Functions and Capabilities and Relationships' Configurations}

The individual and comparative analysis of the cases revealed both expected and unexpected aspects of the process of value co-creation, namely of the impact of supplier management on how suppliers contribute to the customer's performance. Table 1 illustrates the different functions and capabilities that both firms seek in their suppliers and the diversity of interfaces used to access them. It highlights Adira's preference for the utilization of efficiency goals (direct functions) through specified or standardized interfaces and Bosch Termotec's willingness to pursue co-creation goals (indirect functions) though increasingly interactive interfaces.

Table 1. Comparison of dyads' characteristics

\begin{tabular}{lll}
\hline Relationships' characteristics & Adira & Bosch Termotec \\
\hline Value creation & - One side & - Both sides \\
& - Value is created by the supplier who delivers & - Value is co-created by both supplier and buyer \\
\hline it to the buyer & Direct functions & Indirect functions \\
\hline Suppliers' capabilities being explored & - Production (subcontracted) & - Production \\
\hline Technical interfaces & - Knowledge (components) & - Knowledge \\
\hline Complexity and intensity & - Specified (subcontracted) & - Interactive \\
\hline Atmosphere & - Standardized (components) & - Specified \\
\hline Continuity & - High (subcontracted) & Variable (according to the buying process phases) \\
\hline Mutual knowledge & - Low (components) & Satisfactory \\
\hline Symmetry and density of information & - Low density & - Asymmetric \\
\hline flows & Satisfactory & Usually long (average relationship age: 12 years) \\
\hline
\end{tabular}

The data presented in this table does not sustain the existence of a clear link between the production or knowledge nature of suppliers' capabilities being explored by the customer and the type of relationships used to explore them. For instance, relationship atmosphere and continuity are similar in both cases; production capabilities may be supported by highly complex and intense relationships (Adira-subcontracted suppliers) or by low complex and intense relationships (Bosch Termotec's components production phase); knowledge capabilities may be supported by distant relationships (Adira-component suppliers) or close relationships (Bosch Termotec's component development phase).

In this context, the typology of technical interfaces proposed by Araújo et al. (1999) was a useful tool for analyzing customer-supplier dyads in both cases. In the next paragraphs, the evidence produced in this area is analyzed in more detail.

Adira's uses specified interfaces with its subcontracted suppliers and has a clear dominant role. The capabilities in use by both partners are different (Adira uses knowledge capabilities while the suppliers use production 
capabilities) and used sequentially.

First, Adira uses its knowledge capabilities to specify the parts and production processes and then the suppliers use their production capabilities to manufacture the parts. In this case, customer-supplier interaction may be low and information flows are normally unidirectional. As Figure 3A shows, firm boundaries are quite clear: the customer works as a kind of black box inasmuch as suppliers have very limited knowledge about the customer, namely the context of utilization of the parts they produce. Adira's subcontracted suppliers ignore how the parts they manufacture are integrated in Adira's machines, making it impossible for them to suggest any changes even if they want or are able to do it. However, as the specification process requires the customer to be knowledgeable on various aspects of production activities (equipment, processes, materials and so on) in order to set the guidelines for the suppliers to execute these activities, suppliers' boundaries need to be less opaque than those of the customers.

\section{A}

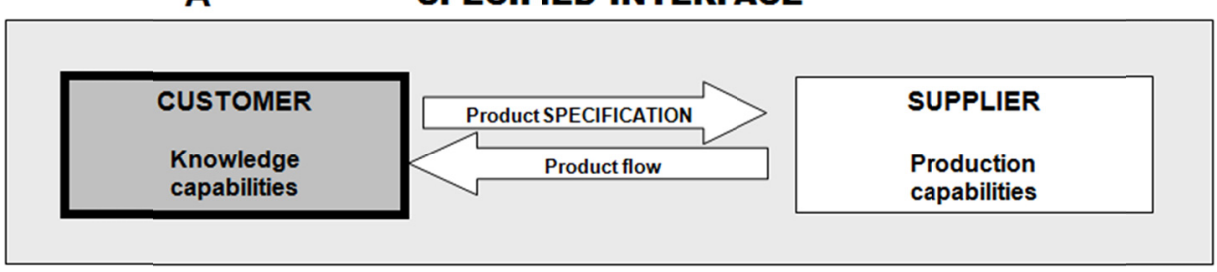

B STANDARDIZED INTERFACE

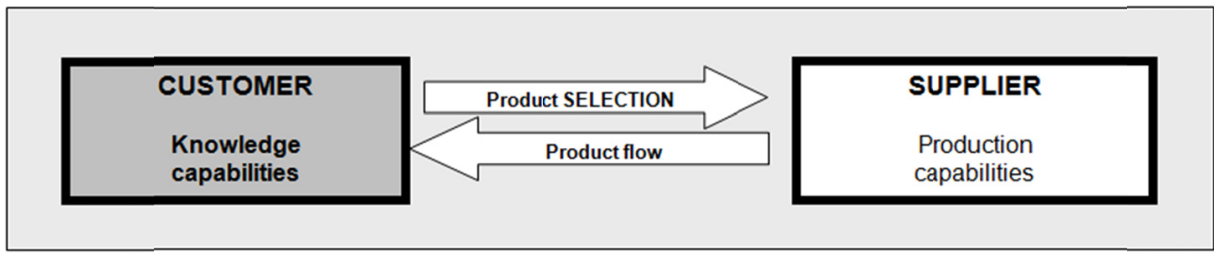

C CO-CREATIVE INTERFACE

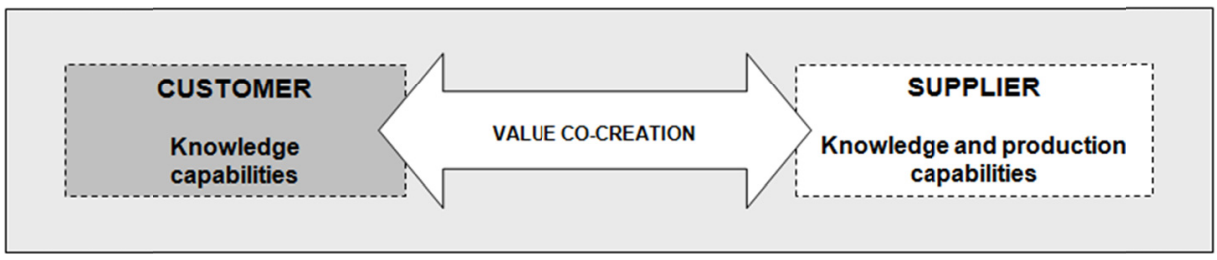

Figure 3. Capabilities and firms' boundaries

In the standardized interfaces that characterize the relationships between Adira and its component suppliers, both parts use similar knowledge capabilities also in a sequential process (Figure 3B). Suppliers use their knowledge capabilities to design the parts and thereafter the customer uses its own knowledge capabilities to select the right part and to integrate it in its machines. In this case, suppliers' products are not influenced by the specific context of the customer, which does not interfere in their definition. Mutual knowledge and information flows may be minimal and both firms work as black boxes. The access of knowledge capabilities is thus compatible with relationships with low interaction, complexity and intensity, close to transactional models.

When both parties are involved in value co-creation processes, the picture is quite different-relationships are more interactive, different capabilities from the customer and the suppliers are used simultaneously, and firms' boundaries are less clear, as illustrated in Figure 3C.

In these cases, as shown by the dyads between Bosch Termotec and various suppliers, knowledge and innovation cannot be attributed exclusively to one of the actors. Rather, they are largely co-produced within interactive relationships characterized by dense and bi-directional information flows. Furthermore, production knowledge goes beyond actors' production activities in order to create a common base of language and technical contexts that seems indispensable to the development, execution and evaluation of the more complex tasks of development. The creation of this common knowledge and the integration of some activities are also reflected 
and reflect a blurring of firms' boundaries that enhances further integration and provides opportunities for mutual influence and learning.

As Figure 3 makes evident, suppliers' production and knowledge capabilities can be accessed and combined with the customer's own capabilities using different types of technical interfaces integrating different relational configurations and requiring different firm boundaries. As such, it seems impossible to define a fixed relationship profile that can be associated to a specific type of supplier capability being explored by a customer.

However, a deeper analysis of this issue reveals that if one considers different ways of using suppliers' capabilities, some relational features seem to emerge in a more consistent way. These dissimilar uses are related to Loasby's notions of static and dynamic capabilities. The evidence from the cases suggests that a firm may be interested in a supplier mainly for its production resources and capabilities and/or for its knowledge resources and capabilities, but this can be achieved in a more static or dynamic way. In fact, in the first situation, the relationship organization may grant the supplier no space for any kind of initiative to reconfigure the product, the production process or both, leading to a static deployment of its resources and capabilities, as shown in the case of Adira. Alternatively, the customer may be opened to the suppliers' initiatives and suggestions (whether they emerge from their set of experiences with other firms or not) that can result in changes of materials, products and processes, leading to new ways of combining the resources, activities and capabilities of customer and supplier, as in the case of Bosch Termotec. In an analogous way, knowledge capabilities may also be used in more static or dynamic ways.

The notions of access, exploration and development as proposed by Araújo et al. (2003) represent increasingly dynamic ways of using suppliers' capabilities and, thus of co-creating value. The joint analysis of these different uses of suppliers' capabilities and the different technical interfaces between customer and supplier may lead to a better understanding of the links between capabilities and relationship configuration. The cases of Adira and Bosch Termotec suggest that relationships' informational content and symmetry, interactivity degree and firm boundaries are the features that seem to be more influential on the way suppliers' capabilities are accessed.

Figure 4 offers a typology of patterns of value creation with suppliers on the basis of the way their capabilities are used and accessed. It shows that there is a continuum of interfaces with suppliers, ranging from a 'mere' access to current suppliers' capabilities to the full use and development of dynamic capabilities. Standardized/specified, translated and co-creative are just three types of interfaces within that continuum.

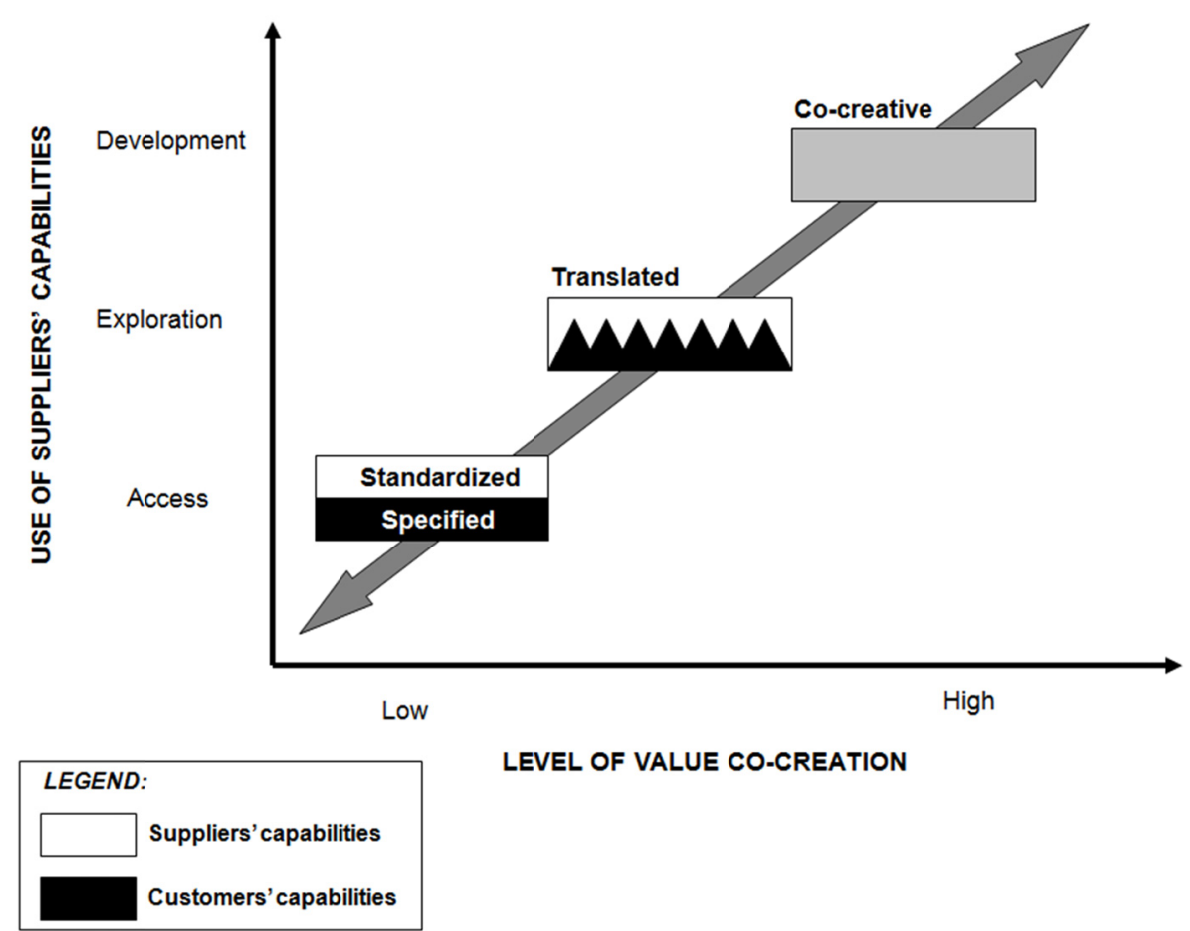

Figure 4. Patterns of value creation with suppliers 
When the buying firm is 'only' trying to access the current suppliers' capabilities, specified and standardized interfaces seem to be an adequate and efficient way of organizing that access. In both cases, low levels of interaction, information density and reciprocity are common traits of relationships. Firm borders may be clearly established and the customer normally assumes a black-box position, controlling the information conveyed to the suppliers. Information flows are usually limited and restricted to aspects of product and process specification or selection of components.

On the contrary, in the case of co-creative interfaces, when actors aim at co-creating value by interacting in order to introduce new solutions in products or processes, there is a higher proportion of shared or co-produced resources, capabilities and activities. As Bosch Termotec's dyads show, there are periods when customer and supplier perform their activities in parallel and others when they come together to create common production, quality and logistic tools and procedures. Because in industrial contexts, innovation is not an abstract process, but rather is directed to concrete problems that are part of specific production and user contexts, customer and suppliers must be quite knowledgeable about their counterparts in order to be effective in this area. Thus, firms tend to become more transparent, borders thinner and fuzzier, buyer-supplier integration higher, and information flows denser and more symmetric. In this scenario, counterparts can be rather active in producing suggestions that may help their counterparts solve specific problems or, in a more general way, be more productive and add more value to their businesses. Bosch Termotec and some of its suppliers stress the importance of this mutual collaboration and how benefits for both parties can be created and enhanced in this way.

However, in order for this to occur, knowledge of each other may have to go beyond the technical capabilities, activities or resources. In fact, suppliers' technical dimensions may be led by a strategic view of the customer's business, calling for strong relational (indirect) and dynamic capabilities from both parties. As Bosch Termotec's purchasing manager states, "suppliers' relational and strategic capabilities are the base for their strong technical capabilities". In this sense, this manager stresses that the source of value of some suppliers is "not just their technical capabilities (...). It is much more than that. It is the spirit of the business that precedes the need to create internal technical capabilities". Furthermore, the knowledge required in this type of interactive relationship may, in fact, include aspects that are not technical or production in nature, namely information about counterpart's networks of relationships and strategies. This requires the willingness to mutually disclose this type of information and solid relational and strategic capabilities to interpret and use it in actions that may benefit both counterparts.

If the static/dynamic use of suppliers' capabilities seems to be closely related to some dimensions of relationships, the link between relationships' configurations and capabilities is not limited to these aspects. In addition, relationships' configurations may influence the perception and evaluation of suppliers' resources and capabilities and, consequently, their utilization by the customer. This idea is developed in the next paragraphs.

\subsection{Relationships' Configurations and the Supply Management Process}

The comparative analysis of the cases will now focus on the link between relational configurations and the perception of supplier capabilities' usefulness to the customer, as suggested by Mota and Castro (2005). Table 2 summarizes the characteristics of buyer-supplier relationships that seem more relevant in this context.

Table 2. Comparison of dyads' characteristics and capabilities perception

\begin{tabular}{|c|c|c|}
\hline Relationships' characteristics & Adira & Bosch Termotec \\
\hline Scope of capabilities perceived by the customer & $\begin{array}{l}\text { Restricted to those used within the } \\
\text { relationship }\end{array}$ & Wider than those used within the relationship \\
\hline $\begin{array}{l}\text { Convergence of perceptions about suppliers, } \\
\text { capabilities }\end{array}$ & $\begin{array}{l}\text { - High (subcontracted) } \\
\text { - Low (catalog) }\end{array}$ & High \\
\hline $\begin{array}{l}\text { Functions and capabilities integrated in the } \\
\text { selection and evaluation processes }\end{array}$ & $\begin{array}{l}\text { - Efficiency functions } \\
\text { - Static capabilities } \\
\text { - Direct capabilities }\end{array}$ & $\begin{array}{l}\text { - Efficiency functions } \\
\text { - Innovation functions } \\
\text { - Static capabilities } \\
\text { - Dynamic capabilities } \\
\text { - Direct capabilities } \\
\text { - Indirect capabilities }\end{array}$ \\
\hline
\end{tabular}




\begin{tabular}{lll}
\hline Appreciation of suppliers' initiatives & Low & High \\
\hline Nature of evaluation criteria & Quantitative & - Quantitative \\
& & - Qualitative \\
\hline Time horizon & Short term & - Short term \\
\hline Value creation & & - Long term \\
\hline
\end{tabular}

The analysis of Tables 1 and 2 suggests that relationships that are more intense and complex (Adira-subcontracted suppliers and Bosch Termotec), more interactive and exhibit a stronger informational density and symmetry (Bosch Termotec) seem to enhance a wider and more rigorous knowledge about the suppliers and their internal and external contexts, allowing customer and supplier to develop similar views of the latter's capabilities. For instance, Adira's view about the capabilities of the catalog suppliers is substantially different from their own view, as they believe that their set of capabilities is wider and more sophisticated than the customer thinks. On the other hand, the dyads between Bosch Termotec and its suppliers are usually more interactive and both parties describe similar pictures of suppliers' capabilities, even when these are only partially used by Bosch Termotec.

Furthermore, selection and evaluation processes seem to play an important role in the development of perception of suppliers' capabilities. On the buying side, actors tend to focus on and value in suppliers the dimensions that integrate the selection and evaluation processes, and disregard the dimensions that are excluded from those processes. On their side, suppliers tend to focus on the dimensions that are positively valued by the customer, regardless of the value that these aspects have for them. Significantly, in both cases, the parties share a common vision about the type of benefits that the focal companies are looking for in their suppliers, suggesting that customers' expectations are effectively communicated to suppliers.

This communication can assume the nature of both explicit and implicit signals. Selection and evaluation processes represent the more explicit tools, as the criteria included in these processes are rather formal and well known by all the actors involved. In the case of Adira, selection and evaluation criteria are restricted to efficiency (direct) functions and the static capabilities that support these functions become the focus of attention. In the case of Bosch Termotec, selection and evaluation factors are related to the exploration and development of suppliers' capabilities, and this is reflected in their willingness to exhibit all their capabilities, even those not used by the customer at a given moment.

Moreover, interaction processes provide the actors with implicit signals or clues about what is expected from the suppliers. On one hand, the mobilization efforts and investments made by the customer are consistently aligned with their supplier-management goals. Thus, these actions implicitly reinforce the importance given to the capabilities that are perceived as being most valuable to the achievement of the customer's goals, and guide the actions taken by suppliers in order to respond to those goals. On the other hand, the way actors act and react also influences their perception of suppliers' capabilities and the way they are valued. In a somewhat circular way, Adira favors a passive attitude from the suppliers, which they assume either because this suits their interests or because they fear the customer will react negatively to their initiatives. The passivity of suppliers feeds Adira's perception of the limitation of suppliers' capabilities and reinforces its attitudes towards them. In fact, Adira's visions reflect a partial and static view of its suppliers' inventory of capabilities that exist or may have changed without the customer noticing it. In its turn, Bosch Termotec encourages and values a proactive attitude from its suppliers, and this is echoed in their actions and support capabilities. This produces a more convergent and dynamic perception of its suppliers' capabilities. A very interesting aspect is that, contrary to the findings of Barnes et al. (2007), the perceptual gaps do not become smaller with time. It seems that when the customer has a restricted and/or distorted view of supplier capabilities, the relational configuration and process seem to crystallize that view and, thus, to limit the possibility of acknowledging and taking advantage of all the supplier capabilities.

\section{Conclusions}

The main contribution of this paper is that co-creating value with suppliers is not a recipe. It is not the 'right' solution in all instances. Rather, value co-creation involving suppliers must be regarded as a strategic option 
which depends on several conditions. This research puts in evidence two of these conditions: suppliers' capabilities and the way the buyer-seller relationships are configured.

In more detail, the paper encompasses both conceptual and managerial contributions. First it explores the complementarities between the Capabilities Approach and the IMP conceptual framework at several levels. The concept of direct and indirect functions is enriched by the multiple views of capabilities discussed before. In fact, the issue of relationships' direct and indirect functions is analyzed in the IMP approach more in terms of the sources and points of impact of their effects than in terms of the capabilities required to produce them. The association of static/direct capabilities with direct functions and of dynamic/indirect capabilities with indirect functions may contribute to a better understanding of how this impacts on value co-creation. In addition, the study confirmed empirically that the suppliers' profile of capabilities is just one factor, among others, that is likely to affect those functions. The customer's capabilities profile is equally important to its ability to create and mobilize relationships adequate to fulfill the desired value creation goals.

In addition, the paper introduces and discusses three important concepts that deserve our final attention: 'continuum range of interfaces', 'relational signals' and 'selective radar'. The comparative analysis of the cases suggests that the combination of goals customers pursue with the capabilities of each supplier results in different relational formats. However, the differentiation of capabilities in terms of production capabilities and knowledge capabilities, as proposed by Fine and Whitney (1996), seems to have no consequence in terms of the configuration of the relationships built to access them. Actually, more relevant than the nature of the capabilities is the degree of dynamism of their utilization, which has a visible impact on the relationships' interactivity and informational density and symmetry. The research puts in evidence the existence of a 'continuum range of interfaces' where, as ones moves from the 'mere' one-side value creation to value co-creation, relationships change and some dimensions, such as interactivity, symmetry and density, become more important for supporting the growing complexity involved.

The higher interactivity, informational density and symmetry of relationships that aim to co-create value with suppliers are accompanied by the dilution of firms' boundaries. This dilution enhances the acquisition of mutual knowledge that sustains the combination and co-development of capabilities, resources and activities of both customers and suppliers. The research confirmed the distinction between activity and knowledge boundaries as proposed by Brusoni and Prencipe (2001). Still, we went further. When the exploration of suppliers' indirect functions is at stake-i.e., both parties are engaged in value co-creation - this study revealed a gap between the activity and knowledge boundaries that is wider than suggested by these authors. As indirect functions (innovation and network) are fostered by the diversity of supplier's counterparts, customers may feel the need to understand those connections. In this situation, knowledge boundaries tend to expand into the suppliers' network positioning.

In addition, the investigation of the link between relationship types and the perception and evaluation of suppliers' capabilities led to the identification of a group of 'relational signals' that have a significant impact on how suppliers' capabilities are used to co-create value. Relationships hold implicit and explicit signs that are important in this context. The former have to do with relationships' configurations while the latter have to do with suppliers' selection and evaluation criteria.

The third concept we have to emphasize is that of 'selective radar'. As a matter of fact, the selection and evaluation processes act as a kind of 'selective radar' that guides the attention of customers to the type of suppliers' resources and capabilities that are likely to create value in those processes. This may block the acknowledgement or, at least, the valuation of the excluded dimensions. As suppliers' endowment of capabilities and resources do not necessarily coincide with those sought by the customers, this may produce a distorted or reduced vision of suppliers' capacities. Furthermore, relational practices seem to reinforce these processes. The study suggested that when relationships are close, interactive and stimulate suppliers' initiatives, customers have a more realistic perception of suppliers' capabilities and resources, enabling their subsequent co-utilization. Thus, the effects of relationships may hinder firms from knowing the actual resources and capabilities of their suppliers, either because they do not attribute them any value, or because suppliers do not reveal them. Thus, a narrow and static definition of supplier's selection and evaluation criteria (e.g., if exclusively focused on efficiency dimensions) and the preference for distant relationships dominated by the customer may obstruct the recognition of contribution potential of suppliers.

In short, since the functions that customers seek in suppliers are conditioned by their own judgment on the latter's skills, the perception and evaluation of resources and capabilities are essential issues in buyer-supplier interfaces. Our research shows that there may be a significant gap between the image that customers hold in their 
minds of their suppliers' bundle of resources and capabilities and reality. In this context, supplier selection, evaluation processes and relationship configuration are important causal factors to this situation, conditioning the perception and evaluation of suppliers and, consequently, the use of their resources and capabilities to the benefit of the buying firm.

With respect to managerial implications, this paper makes clear how the implicit and explicit signals existing in relationships may condition the effective perception managers have about suppliers' capabilities, and thus the definition of their potential to the value creation in their firms. Managers must also be aware of unexpected and unintended effects that firms' decisions and actions regarding their suppliers may have on the type of value suppliers may add to the customer's business. In fact, even dimensions that seem to have clear cut effects, such as the definition of selection and evaluation criteria, may have a wide impact on the interpretation of what is expected from suppliers and how they should behave to strengthen their positioning vis-à-vis the customer. A restrictive definition of those expectations (namely by focusing exclusively on rationalization goals) and an over-dominant role on the side of the customer may seem (and be) quite effective in the short run, but may also result in a distorted picture of the suppliers' potential, hindering the possibility of fully exploring that potential to the customer's benefit.

It is also hoped that the paper help managers to understand how their firms need to assure that they are doing their part of the job. Are they investing and allocating the needed resources? Are they shrinking or stretching firm boundaries and setting the appropriate level of interaction with suppliers? Are they providing their suppliers with opportunities to learn and develop new capabilities and resources? In short, finding interesting suppliers is just a step in making the most out of them. Being an interesting customer and building interesting relationships for the supplier are also issues of paramount importance that should be on the agenda of any manager.

\section{References}

Aarikka-Stenroos, L., \& Jaakkola, E. (2012). Value Co-creation in Knowledge Intensive Business Services: A Dyadic Perspective on the Joint Problem Solving Process. Industrial Marketing Management, 41(1), 15-26. http://dx.doi.org/10.1016/j.indmarman.2011.11.008

Anderson, J. C., Håkansson, H., \& Johanson, J. (1994). Dyadic business relationships within a business network context. Journal of Marketing, 58(4), 1-15. http://dx.doi.org/10.2307/1251912

Araújo, L., Dubois, A., \& Gadde, L. E. (1999). Managing interfaces with suppliers. Industrial Marketing Management, 28(5), 497-506. http://dx.doi.org/10.1016/S0019-8501(99)00077-2

Araújo, L., Dubois, A., \& Gadde, L. E. (2003). The multiple boundaries of the firm. Journal of Management Studies, 40(5), 1255-1277. http://dx.doi.org/10.1111/1467-6486.00379

Avery, S. (1999). Supplier alliances help power Wisconsin Electric. Purchasing, June 3.

Barnes, B. R., Naudé, P., \& Michell, P. (2007). Perceptual gaps and similarities in buyer-seller relationships. Industrial Marketing Management, 36(5), 662-675. http://dx.doi.org/10.1016/j.indmarman.2006.04.004

Baxter, R., \& Matear, S. (2004). Measuring intangible value in business to business buyer-seller relationships: An intellectual capital perspective. Industrial Marketing Management, 33(6), 491-500. http://dx.doi.org/10.1016/j.indmarman.2004.01.008

Birch, D. (2001). Staying on good terms. Supply Management, April, 36-37.

Blois, K. (1998). Don’t all firms have relationships? Journal of Business \& Industrial Marketing, 13(3), 256-270. http://dx.doi.org/10.1108/08858629810222289

Boyd, D. E., \& Spekman, R. (2004). Internet Usage within B2B Relationships and Its Impact on Value Creation: A Conceptual Model and Research Propositions. Journal of Business-to-Business Marketing, 11(1/2), 9-34. http://dx.doi.org/10.1300/J033v11n01_03

Brusoni, S., \& Prencipe, A. (2001). Unpacking the blackbox of modularity: technologies, products and organizations. Industrial and Corporate Change, 10(1), 179-205. http://dx.doi.org/10.1093/icc/10.1.179

Cannon, J. P., \& Homburg, C. (2001). Buyer-suppliers relationships and customer firm costs. Journal of Marketing, 65(1), 29-43. http://dx.doi.org/10.1509/jmkg.65.1.29.18136

Chakkol, M., Johnson, M., Raja, J., \& Raffoni, A. (2014). From Goods to Solutions: How does the Content of an Offering Affect Network Configuration? International Journal of Physical Distribution \& Logistics Management, 44(1/2), 28-60.

Cova, B., \& Salle, R. (2008). Marketing solutions in accordance with the S-D logic: Co-creating value with 
customers network actors. Industrial Marketing Management, 37(3), $270-277$. http://dx.doi.org/10.1016/j.indmarman.2007.07.005

Croom, S., \& Batchelor, J. (1997). The development of strategic capabilities - an interaction view. Integrated Manufacturing Systems, 8(5), 299-312. http://dx.doi.org/10.1108/09576069710179751

Day, M., Fawcett, S., Fawcett, A., \& Magnan, G. (2013). Trust and Relational Embeddedness: Exploring a Paradox of Trust Pattern Development in Key Supplier Relationships. Industrial Marketing Management, 42(2), 152-165. http://dx.doi.org/10.1016/j.indmarman.2012.12.004

Dubois, A. (1998). Organizing Activities across Firm Boundaries. London: Routledge. http://dx.doi.org/10.4324/9780203280324

Dubois, A., \& Araújo, L. (2004). Research methods in industrial marketing studies. In H. Håkansson, D. Harrison \& A. Waluszewski (Eds.), Rethinking Marketing: Developing a New Understanding of Markets (pp. 207-227). Chichester: John Wiley \& Sons.

Dubois, A., \& Gadde, L. E. (2002). Systematic combining: an abductive approach to case research. Journal of Business Research, 55(7), 553-560. http://dx.doi.org/10.1016/S0148-2963(00)00195-8

Easton, G. (1995). Methodology and industrial networks. In K. Möller \& D. Wilson (Eds.), Business Marketing: An Interaction and Network Perspective (pp. 411-492). Norwell, MA: Kluwer. http://dx.doi.org/10.1007/978-94-011-0645-0_15

Easton, G. (1998). Case research as a methodology for industrial networks: A realist apologia. In P. Naudé \& P. Turnbull (Eds.), Network Dynamics in International Marketing (pp. 73-87). Oxford: Pergamon Press.

Eggert, A., \& Ulaga, W. (2002). Customer perceived value: A substitute for satisfaction in business markets? Journal of Business and Industrial Marketing, 17(2/3), $107-118$. http://dx.doi.org/10.1108/08858620210419754

Ehret, M. (2004). Managing the trade-off between relationships and value networks. Towards a value-based approach of customer relationship management in business-to-business markets. Industrial Marketing Management, 33(6), 465-473. http://dx.doi.org/10.1016/j.indmarman.2004.03.002

Eisenhardt, K. (1989). Building Theories from Case Study Research. Academy of Management Review, 14(5), $532-550$.

Eng, T. Y. (2005). The Effects of Learning on Relationship Value in a Business Network Context. Journal of Business-to-Business Marketing, 12(4), 67-102. http://dx.doi.org/10.1300/J033v12n04_03

Engelseth, P., \& Törnroos, J. (2013). Timing Value Co-creation in Supply Networks. Paper presented at the 29th IMP Conference, Atlanta.

Fine, C. H., \& Whitney, D. E. (1996). Is the make-buy decision process a core competence? Paper presented at the MIT IMVP Sponsors' Meeting, San Paulo.

Florén, H., \& Lee, C. (2013). The Business Model and Supply Strategy: What is the Connection between Them? Paper presented at the 20th EurOMA Conference, Dublin.

Ford, D., Gadde, L. E., Håkansson, H., Lundgren, A., Snehota, I., Turnbull, P., \& Wilson, D. (1998). Managing Business Relations. Chichester: John Wiley \& Sons.

Ford, D., Gadde, L. E., Håkansson, H., \& Snehota, I. (2003). Managing Business Relationships (2nd ed.). Chichester: John Wiley \& Sons.

Ford, D., \& McDowell, R. (1999). Managing business relationships by analysing the effects and value of different actions. Industrial Marketing $429-442$. http://dx.doi.org/10.1016/S0019-8501(99)00065-6

Foss, N. J. (1999). Networks, capabilities and competitive advantage. Scandinavian Journal of Management, 15(1), 1-15. http://dx.doi.org/10.1016/S0956-5221(98)00030-X

Foss, N. J., \& Loasby, B. (1998). Coordination and capabilities. In N. Foss \& B. Loasby (Eds.), Economic Organization, Capabilities and Coordination: Essays in Honour of G. B. Richardson (pp. 1-13). London: Routledge.

Gadde, L. E., \& Persson, G. (2004). Developments on the supply side of the companies. In H. Håkansson, D. Harrison, \& A. Waluszewski (Eds.), Rethinking Marketing: Developing a New Understanding of Markets (pp. 161-186). Chichester: John Wiley \& Sons. 
Gadde, L. E., \& Snehota, I. (2000). Making the most of supplier relationships. Industrial Marketing Management, 29(4), 305-316. http://dx.doi.org/10.1016/S0019-8501(00)00109-7

Gelderman, C. J., \& Van Weele, A. (2005). Purchasing Portfolio Models: A Critique and Update. The Journal of Supply Chain Management, Summer, 19-28. http://dx.doi.org/10.1111/j.1055-6001.2005.04103003.x

George, A. L., \& Benett, A. (2005). Case Studies and Theory Development in the Social Sciences. Cambridge: The MIT Press.

Grönroos, C. (2006). Adopting a service logic for marketing. Marketing Theory, 6(3), 317-334. http://dx.doi.org/10.1177/1470593106066794

Grönroos, C. (2011). A Service Perspective on Business Relationships: The Value Creation, Interaction and Marketing Interface. Industrial Marketing Management, 40(2), 240-247. http://dx.doi.org/10.1016/j.indmarman.2010.06.036

Håkansson, H., \& Johanson, J. (1993). Industrial Functions of Business Relationships. In D. Sharma (Ed.), Industrial Networks (pp. 13-30). Greenwich, Connecticut: JAI Press Inc.

Håkansson, H., \& Snehota, I. (1995). Developing Relationships in Business Networks. London: Routledge.

Halinen, A., \& Törnroos, J. A. (1995). The meaning of time in the study of industrial buyer-supplier relationships. In K. Möller \& D. Wilson (Eds.), Business Marketing: An Interaction and Network Perspective (pp. 493-529). Norwell, MA: Kluwer. http://dx.doi.org/10.1007/978-94-011-0645-0_16

Hammervoll, T. (2005). Transactional and Value Creational Sources of Dependence. Journal of Business-to-Business Marketing, 12(4), 41-66. http://dx.doi.org/10.1300/J033v12n04_02

Handfield, R. B., Ragatz, G. L., Petersen, K. J., \& Moncza, R. M. (1999). Involving suppliers in new product development. California Management Review, 42(1), 59-82. http://dx.doi.org/10.2307/41166019

Hedaa, L., \& Törnroos, J. A. (2008). Understating Event—based Business Networks. Time \& Society, 17(2/3), 319-348. http://dx.doi.org/10.1177/0961463X08093427

Hogan, J. (2001). Expected relationship value: A construct, a methodology for measurement and a modeling technique. Industrial Marketing Management, 30(4), 339-351. http://dx.doi.org/10.1016/S0019-8501(01)00152-3

Holmen, E., Aune, T., \& Pedersen, A. (2013). Network Pictures for Managing Key Suppliers Relationships. Industrial Marketing Management, 42(2), 139-151. http://dx.doi.org/10.1016/j.indmarman.2012.12.003

Ivens, B., Vijver, M., \& Vos, B. (2013). Managing and Developing Key Supplier Relationships: An Introduction to the Special Issue, Discussion and Implications. Industrial Marketing Management, 42(2), 135-138. http://dx.doi.org/10.1016/j.indmarman.2013.01.002

Johnsen, R. E., \& Ford, D. (2006). Interaction capability development of smaller suppliers in relationships with larger customers, Industrial Marketing Management, 35, 1002-1015. http://dx.doi.org/10.1016/j.indmarman.2006.05.005

Johnsen, R. E., \& Ford, D. (2008). Exploring the concept of asymmetry: A typology for analysing customer-supplier relationships. Industrial Marketing Management, 37, 471-483. http://dx.doi.org/10.1016/j.indmarman.2007.05.004

Kim, D., Cavusgil, S., \& Cavusgil, E. (2013). Does IT Alignment Between Supply Chain Partners Enhance Customer Value Creation? An Empirical Investigation. Industrial Marketing Management, 42(6), 880-889. http://dx.doi.org/10.1016/j.indmarman.2013.05.021

La Rocca, A., \& Snehota, I. (2014). Value Creation and Organizational Practices at Firm Boundaries. Management Decision, 52(1), 2-17. http://dx.doi.org/10.1108/MD-04-2013-0229

Leroy, J., Cova, B., \& Salle, R. (2012). The Value Co-Creation Concept: Mixing Up Apples and Oranges? Paper presented at the 28th IMP Conference, Rome.

Lindberg, N., \& Nordin, F. (2008). From products to services and back again: Towards a new service

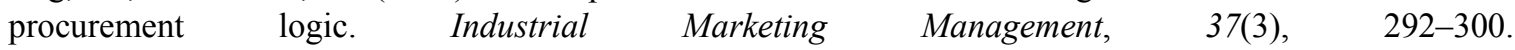
http://dx.doi.org/10.1016/j.indmarman.2007.07.006

Loasby, B. (1996). The Organization of Industry. In N. Foss \& C. Knudsen (Eds.), Towards a Competence Theory of the Firm (pp. 38-53). London: Routledge. 
Loasby, B. (1998a). The Concept of Capabilities. In N. Foss \& B. Loasby (Eds.), Economic Organization, Capabilities and Coordination: Essays in Honour of G. B. Richardson (pp. 163-182). London: Routledge.

Loasby, B. (1998b). The organization of capabilities. Journal of Economic Behavior and Organization, 35(2), 139-160. http://dx.doi.org/10.1016/S0167-2681(98)00056-0

Lusch, R., \& Vargo, S. (Eds.) (2006a). The Service-dominant Logic of Marketing: Dialog, Debate, and Directions. Armonk, New York: M. E. Sharpe.

Lusch, R., \& Vargo, S. (2006b). Service-dominant logic: Reactions, reflections and refinements. Marketing Theory, 6(3), 281-288. http://dx.doi.org/10.1177/1470593106066781

Makkonen, H., \& Olkkonen, R. (2013). The Conceptual Locus and Functionality of Key Supplier Management: A Multi-dyadic Qualitative Study. Industrial Marketing Management, 42(2), 189-201. http://dx.doi.org/10.1016/j.indmarman.2012.12.007

Martinez, M. (2013). Co-creation of Value by Open Innovation: Unlocking New Sources of Competitive Advantage, Agribusiness, 30(2), 1-16.

Matthyssens, P., \& Vandenbempt, K. (2008). Moving from basic offerings to value-added solutions: Strategies, barriers and alignment. Industrial Marketing Management, 37(3), 316-328. http://dx.doi.org/10.1016/j.indmarman.2007.07.008

Matthyssens, P., Vandenbempt, K., \& Berghman, L. (2006). Value innovation in business markets: breaking the industry recipe. Industrial Marketing Management, 35(6), 751-761. http://dx.doi.org/10.1016/j.indmarman.2005.05.013

McIvor, R., Humphreys, P., \& Cadden, T. (2006). Supplier involvement in product development in the electronic industry: A case study. Journal of Engineering and Technology Management, 23(4), 374-397. http://dx.doi.org/10.1016/j.jengtecman.2006.08.006

Mele, C. (2008). Managing value creation within a project: From value delivery sequence to value co-creating network. Paper presented at the $37^{\text {th }}$ EMAC Conference, Brighton.

Mena, C., Humphries, A., \& Choi, T. (2013). Toward a Theory of Multi-tier Supply Chain Management. Journal of Supply Chain Management, 49(2), 58-77. http://dx.doi.org/10.1111/jscm.12003

Menon, A., Homburg, C., \& Beutin, N. (2005). Understanding Customer Value in Business-to-Business Relationships. Journal of Business-to-Business Marketing, 12(2), 1-38. http://dx.doi.org/10.1300/J033v12n02_01

Moeller, S., Fassnacht, M., \& Klose, S. (2006). A Framework for Supplier Relationship Management (SRM). Journal of Business-to-Business Marketing, 13(4), 69-91. http://dx.doi.org/10.1300/J033v13n04_03

Möller, K. (2006). Role of competences in creating customer value. A value-creation logic approach. Industrial Marketing Management, 35(8), 913-924. http://dx.doi.org/10.1016/j.indmarman.2006.04.005

Möller, K., \& Törrönen, P. (2003). Business supplier's value creation potential: A capability-based analysis. Industrial Marketing Management, 32(2), 109-118. http://dx.doi.org/10.1016/S0019-8501(02)00225-0

Mota, J., \& Castro, L. (2005). Relationship portfolios and capability development: Cases from the moulds industry. Journal of Purchasing and Supply Management, 11(1), 42-54. http://dx.doi.org/10.1016/j.pursup.2005.04.002

O'Cass, A., \& Ngo, L. (2012). Creating Superior Customer Value for B2B Firms through Supplier Firm $\begin{array}{llll}\text { Capabilities. Industrial Marketing } & \text { Management, } & 41(1),\end{array}$ http://dx.doi.org/10.1016/j.indmarman.2011.11.018

Oinonen, L., \& Jalkala, A. (2012). Supplier-Customer Co-innovation Process in B2B Markets. Paper presented at the 28th IMP Conference, Rome.

Petersen, K. J., Handfield, R. B., \& Ragatz, G. L. (2005). Supplier integration into new product development: coordinating product, process and supply chain design. Journal of Operations Management, 23(3/4), 371-388. http://dx.doi.org/10.1016/j.jom.2004.07.009

Ragatz, G. L., Handfield, R. B., \& Petersen, K. J. (2002). Benefits associated with supplier integration into new product development under conditions of technology uncertainty. Journal of Business Research, 55(5), 389-400. http://dx.doi.org/10.1016/S0148-2963(00)00158-2

Ragin, C. (2000). Fuzzy-Set Social Science. Chicago: The University of Chicago Press. 
Randall, W., Wittmann, C., Nowicki, D., \& Pohlen, T. (2014). Service-Dominant Logic and Supply Chain Management: Are We There Yet? International Journal of Physical Distribution \& Logistics Management, 44(1/2), 1-27.

Richardson, G. (1972). The organisation of industry. The Economic Journal, 82(327), 883-896. http://dx.doi.org/10.2307/2230256

Richardson, G. (1998). Some Principles of Economic Organization. In N. Foss \& B. Loasby (Eds.), Economic Organization, Capabilities and Coordination: Essays in Honour of G. B. Richardson (pp. 44-61). London: Routledge.

Roseira, C., Brito, C., \& Ford, D. (2013). Network Pictures and Supplier Management: An Empirical Study. Industrial Marketing Management, 42(2), 234-247. http://dx.doi.org/10.1016/j.indmarman.2012.08.006

Rosell, D., Lakemond, N., \& Wasti, S. (2014). Integrating Knowledge with Suppliers at the R\&D-Manufacturing Interface. Journal of Manufacturing Technology Management, 25(2), 1-15. http://dx.doi.org/10.1108/JMTM-12-2013-0171

Roser, T., DeFillippi, R., \& Samson, A. (2013). Managing your Co-creation Mix: Co-creation Ventures in Distinctive Contexts. European Business Review, 25(1), 20-41. http://dx.doi.org/10.1108/09555341311287727

Strauss, A., \& Corbin, J. (1998). Basics of Qualitative Research Techniques and Procedures for developing Grounded Theory. London: Sage.

Ulaga, W. (2003). Capturing value creation in business relationships: A customer perspective. Industrial Marketing Management, 32(8), 677-693. http://dx.doi.org/10.1016/j.indmarman.2003.06.008

Ulaga, W., \& Eggert, A. (2005). Relationship Value in Business Markets: The Construct and its Dimensions. Journal of Business-to-Business Marketing, 12(1), 73-100. http://dx.doi.org/10.1300/J033v12n01_04

Ulaga, W., \& Eggert, A. (2006). Value-based differentiation in business relationships: Gaining and sustaining key supplier status. Journal of Marketing, 70(1), 119-136. http://dx.doi.org/10.1509/jmkg.2006.70.1.119

Valjakka, T., Kansola, M., Hakanen, T., \& Valkokari, K. (2013). Antecedents of Value Co-Creation in B2B Networks. In Y. Shimomura \& K. Kimita (Eds.), The Philosopher's Stone for Sustainability. Berlin: Springer Berlin Heidelberg. http://dx.doi.org/10.1007/978-3-642-32847-3_29

Vargo, S., \& Lusch, R. (2004a). Evolving to a new dominant logic for marketing. Journal of Marketing, 68(1), 1-18. http://dx.doi.org/10.1509/jmkg.68.1.1.24036

Vargo, S., \& Lusch, R. (2004b). The four service marketing myths: Remnants of as goods-based manufacturing model. Journal of Service Research, 6(4), 324-335. http://dx.doi.org/10.1177/1094670503262946

Vargo, S., \& Lusch, R. (2008). From goods to service(s): Divergences and convergences of logics. Industrial Marketing Management, 37(3), 254-259. http://dx.doi.org/10.1016/j.indmarman.2007.07.004

Wagner, S. M., Eggert, A., \& Lindmann, E. (2008). Creating and claiming value in collaborative relationships. Paper presented at the $37^{\text {th }}$ EMAC Conference, Brighton.

Wagner, S. M., \& Johnson, J. L., (2004). Configuring and Managing Strategic Supplier Portfolios. Industrial Marketing Management, 33(8), 717-730. http://dx.doi.org/10.1016/j.indmarman.2004.01.005

Wagner, S. M., \& Hoegl, M. (2006). Involving suppliers in product development: Insights from R\&D directors and project managers. Industrial Marketing Management, 35(8), 936-943. http://dx.doi.org/10.1016/j.indmarman.2005.10.009

Walter, A., Müller, T., Helfert, G., \& Ritter, T. (2003). Functions of industrial supplier relationships and their impact on relationship quality. Industrial Marketing Management, 32(2), 159-169. http://dx.doi.org/10.1016/S0019-8501(02)00230-4

Wilson, D., \& Jantrania, S. (1995). Understanding the value of a relationship. Asia-Australia Marketing Journal, 2(1), 55-66. http://dx.doi.org/10.1016/S1320-1646(94)70278-1 


\section{Copyrights}

Copyright for this article is retained by the author(s), with first publication rights granted to the journal.

This is an open-access article distributed under the terms and conditions of the Creative Commons Attribution license (http://creativecommons.org/licenses/by/3.0/). 